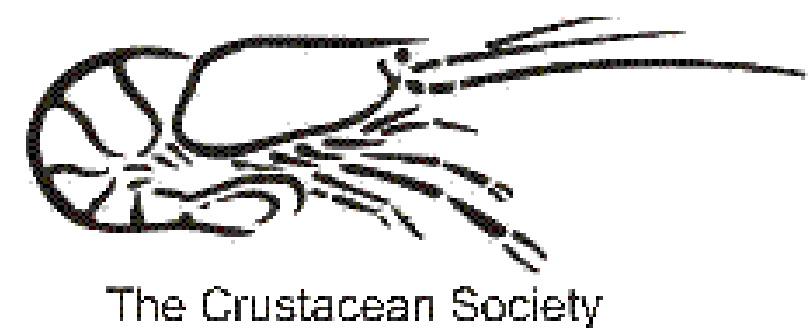

Two Corophioid Amphipods Commensal on Spider Crabs in Newfoundland Author(s): D. H. Steele, R. G. Hooper and D. Keats

Source: Journal of Crustacean Biology, Vol. 6, No. 1 (Feb., 1986), pp. 119-124

Published by: The Crustacean Society

Stable URL: http://www.jstor.org/stable/1547935

Accessed: 01/08/2013 09:41

Your use of the JSTOR archive indicates your acceptance of the Terms \& Conditions of Use, available at http://www.jstor.org/page/info/about/policies/terms.jsp

JSTOR is a not-for-profit service that helps scholars, researchers, and students discover, use, and build upon a wide range of content in a trusted digital archive. We use information technology and tools to increase productivity and facilitate new forms of scholarship. For more information about JSTOR, please contact support@ jstor.org.

The Crustacean Society is collaborating with JSTOR to digitize, preserve and extend access to Journal of Crustacean Biology. 


\title{
TWO COROPHIOID AMPHIPODS COMMENSAL ON SPIDER CRABS IN NEWFOUNDLAND
}

\author{
D. H. Steele, R. G. Hooper, and D. Keats
}

\begin{abstract}
A B S T R A C T
The amphipods Ischyrocerus commensalis and Gammaropsis inaequistylis were found on the spider crab Chionoecetes opilio collected in shallow water in Bonne Bay, Newfoundland. The first and second gnathopods have similar morphologies in these two species.Gammaropsis inaequistylis was also found on another spider crab, Hyas araneus, in Bonne Bay and Conception Bay, Newfoundland.
\end{abstract}

During April-May 1983 and 1984, large numbers of paired snow crabs, Chionoecetes opilio (Fabricius), were found in shallow water (5-30 m) at Bonne Bay on the west coast of Newfoundland. In the course of biological observations in 1983 (Hooper, in press), amphipods were collected from these crabs. In early May 1984 more collections were made from $C$. opilio and from Hyas araneus (Linnaeus). Subsequently, amphipods proved to be common on Hyas araneus not only in Bonne Bay but also on the east coast of Newfoundland. All these collections form the material for the present report.

\section{MATERIALS AND Methods}

Crabs were collected by SCUBA diving, brought into the laboratory for examination, and the amphipods removed and preserved. During transportation and handling some of the amphipods were dislodged and later found in the bottom of the container, so that the numbers observed on the crabs are less than actually occurred (Table 1). The anatomical locations of amphipod occurrence were recorded only for the 1984 collections (Table 2 ).

Biological observations were made only on Gammaropsis inaequistylis, for which reasonable numbers of specimens were available. The head length of the animals was measured with an eyepiece micrometer. Since the amphipods typically curl up when preserved and can be extended only with difficulty, and not without damage, measurements were converted to total length (anterior margin of the head to the distal end of the telson) from a regression relating the two measurements. Embryos in the brood pouch were classified according to their stage of development (Steele and Steele, 1969), counted, and representatives measured with an eyepiece micrometer. Morphological observations were made on living and preserved specimens.

\section{RESULTS}

\section{Occurrence on Crabs}

Two species of amphipods, Gammaropsis inaequistylis (Shoemaker) and Ischyrocerus commensalis Chevreux, were found on Chionoecetes opilio in Bonne Bay. According to Hooper (in press) the infestation rate in 1983 was $18 \%$. Both species occurred in early May but only Gammaropsis inaequistylis was found in late May (Table 1).

Since the early May collections were not kept separate, it is not known whether the two species occurred on different sites on the crabs. Most specimens of Gammaropsis inaequistylis observed in late May on C. opilio were found in the marginal groove at the lower edge of the carapace, except for a few below the eye socket and on the large chela (Table 2). Similarly, G. inaequistylis on Hyas araneus were almost exclusively on the tufts of setae at the base of the carapace just above the origin of the walking legs.

Although both of these species are in genera in which some species are known 
Table 1. Collections of amphipods on spider crabs.

\begin{tabular}{cllcr}
\hline \hline & & & \multicolumn{2}{c}{ Number with amphipods } \\
\cline { 3 - 4 } Date & Location & Crab species & $\begin{array}{c}\text { Ischyrocerus } \\
\text { commensalis }\end{array}$ & $\begin{array}{c}\text { Gammaropsis } \\
\text { inaequistylis }\end{array}$ \\
\hline 12 May 1983 & Bonne Bay & C. opilio & 3 & 14 \\
13 May 1984 & Bonne Bay & C. opilio & 5 & 4 \\
23-24 May 1984 & Bonne Bay & C. opilio & 0 & 38 \\
23-24 May 1984 & Bonne Bay & H. araneus & 0 & 3 \\
8 June 1984 & Conception & H. araneus & 0 & 16 \\
& Bay & & & \\
\hline
\end{tabular}

to construct and live in tubes, neither was found in tubes on the crabs. Gammaropsis inaequistylis rests dorsal side up on the setal tuft, and is closely pressed to the surface of the crab. The brownish bands on the body and the red bands on the third segment of the first antennal peduncle, the fourth and fifth segments of the second antennal peduncle, the seventh segment of pereiopod 2 (gnathopod 2) and segments five and six of pereiopods 3-7 enable it to blend in well with the brownish red colour of the crabs.

\section{Morphology}

A comparison of $G$. inaequistylis and I. commensalis reveals many similarities in their structure. The genera Gammaropsis and Ischyrocerus are currently placed in separate families (Isaeidae $=$ Photidae and Ischyroceridae, respectively) of the Superfamily Corophioidea, primarily on the basis of the structure and armament of their third uropods. However, detailed examination of these two species and of others in each genus shows that the similarities in general structure and in mouthparts outweigh the differences and suggests that the two families or parts of them could be united. However, this paper is not the place to make such a realignment.

The genus Podoceropsis was synonymized with Gammaropsis by Barnard (1973) and this practice is followed here. Conlan (1983), however, on the basis of a study of North Pacific species, retained Podoceropsis, while recognizing its close affinity with Gammaropsis.

Gammaropsis inaequistylis and Ischyrocerus commensalis show striking similarities in the structure of their anterior pereiopods (gnathopods) (Fig. 1) that are presumably due to their similar mode of life. Both species are sexually dimorphic, with the second gnathopods much larger in the male than in the female. The anterior gnathopods are small and subchelate in the males and females of both species. The only obvious difference is that the dactyl in the male of $G$. inaequistylis

Table 2. Distribution of Gammaropsis inaequistylis on Chionoecetes opilio from Bonne Bay (23-24 May 1984) and on Hyas araneus from Conception Bay (8 June 1984).

\begin{tabular}{lcc}
\hline \multicolumn{1}{c}{ Location } & C. opilio & H. araneus \\
\hline $\begin{array}{l}\text { Orbit } \\
\text { Base of walking leg } \\
\begin{array}{l}\text { Marginal groove of } \\
\text { carapace }\end{array}\end{array}$ Dorsal surface of $^{\text {carapace }}$ & 14 & 0 \\
& 18 & 14 \\
\hline
\end{tabular}




\section{I. commensalis}
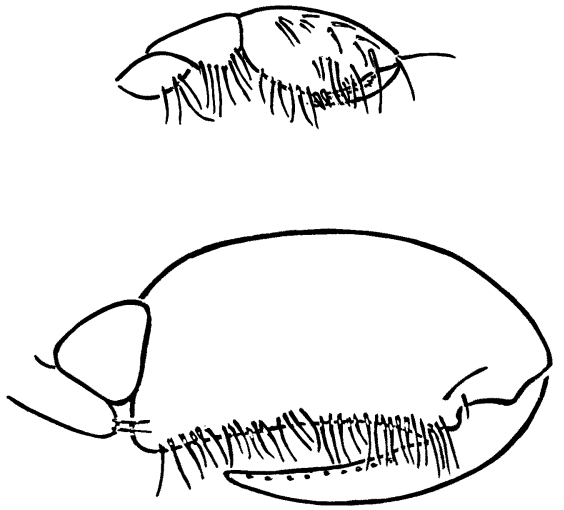

G. inaequistylis

\section{Male}

Gn.1

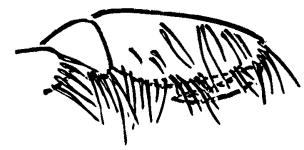

Gn.2

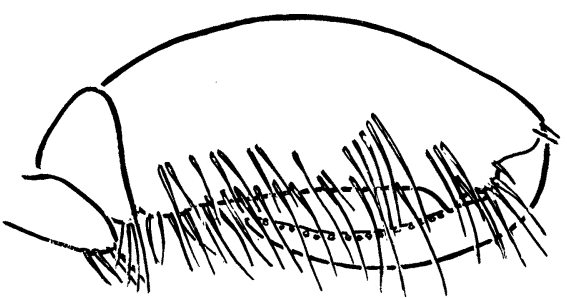

\section{Female}
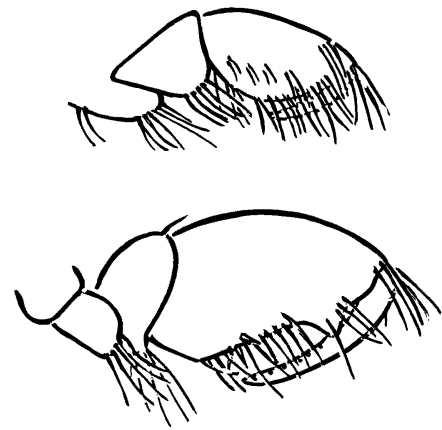

Gn.1

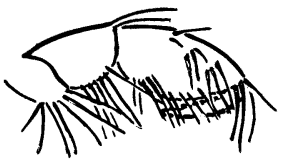

Gn.2

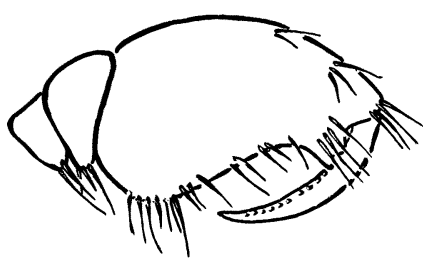

$.5 \mathrm{~mm}$

Fig. 1. Gnathopods of male and female Ischyrocerus commensalis and Gammaropsis inaequistylis.

lacks the row of small teeth found in the females of both species and in the male of I. commensalis. The second gnathopods are larger than the first and similar in the two sexes of the two species. In the females, segment 6 is posteriorly concave and has the palm defined by spine-setae. Distally the curved palm terminates in a toothed projection near the dactyl. The large dactyl has sockets but no teeth. The dactyl reaches the spine-setae in I. commensalis but not in Gammaropsis inaequistylis.

The second gnathopods of the males of both species are also similar to each other. The sixth segments are large, posteriorly concave, and have concave, almost parallel margins. The palm is covered with plumose setae and terminates distally in a projection. The large dactyl has sockets but no teeth in either species. 
BONNE BAY

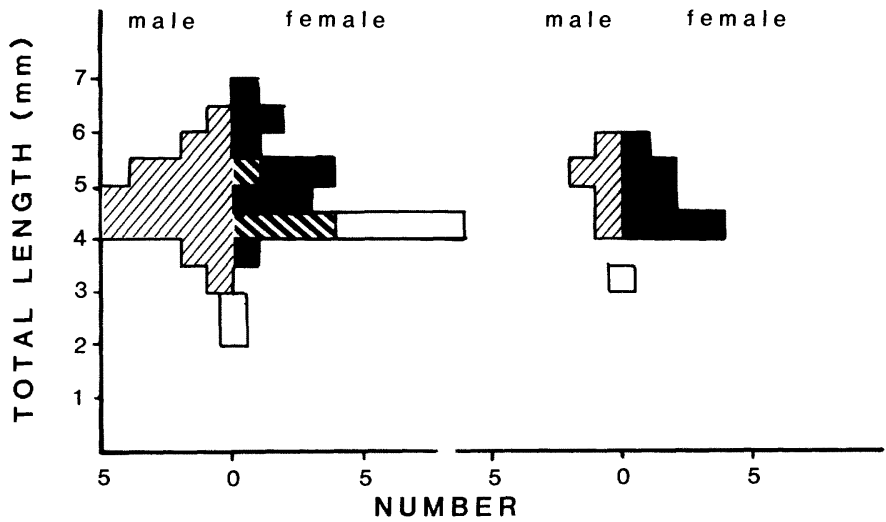

QMale

Female Setose Oostegites

NFemale Nonsetose Oostegites

Immature

Fig. 2. Size compositions of collections of Gammaropsis inaequistylis in Bonne Bay and Conception Bay.

The function of the gnathopods is unknown and it is not clear why those of the males and females differ. Pereiopods 3-7 are not subchelate in either species as they are in the genus Isaea, species of which are also commensal on decapods (Vader, 1983). Other species of Gammaropsis and Ischyrocerus are sexually dimorphic with the anterior gnathopods small and subchelate in both sexes. The sixth segment of the second gnathopod is enlarged and differently shaped in males and females, that of the male of Gammaropsis sophiae being apparently similar in shape to that of the females of $G$. inaequistylis and I. commensalis.

The regression of total length on head length for Gammaropsis inaequistylis is: total length $=8.12$ (head length) $-0.14\left(r^{2}=0.92\right)$.

\section{Biology of Gammaropsis inaequistylis}

The size compositions of $G$. inaequistylis collected on Chionoecetes opilio from Bonne Bay and on Hyas araneus from Conception Bay are similar (Fig. 2). Ovigerous females ranged from 3.8 to $6.6 \mathrm{~mm}$ in calculated total length. Few juveniles were collected on the crabs. The sex ratio of mature animals was 1.05 female to 1.0 male in Bonne Bay and 2.0 females to 1.0 male in Conception Bay.

The average diameter (length + width $/ 2$ ) of stage A eggs was $0.23 \mathrm{~mm}$. Hatched young from the brood pouch were $1.2 \mathrm{~mm}$ in total length. The brood pouches contained young in all stages of development from stage A to newly hatched. The number of eggs in the brood pouch increased linearly with the size of the female (Fig. 3).

\section{DISCUSSION}

Ischyrocerus commensalis was described by Chevreux (1900) from fifteen specimens collected from an asteroid at a depth of $150 \mathrm{~m}$ off Newfoundland (' $\mathrm{Hi}$ rondelle Station 163). Subsequently, 48 specimens were recorded from three stations in the southern Gulf of St. Lawrence by Shoemaker (1930). Besner (1976) reported that these specimens were attracted to bait in a trap, but this fact was not mentioned by Shoemaker (1930). Besner (1976) has recorded them as associated with hermit crabs and Stephensen (1944) from ascidians. They are collected 


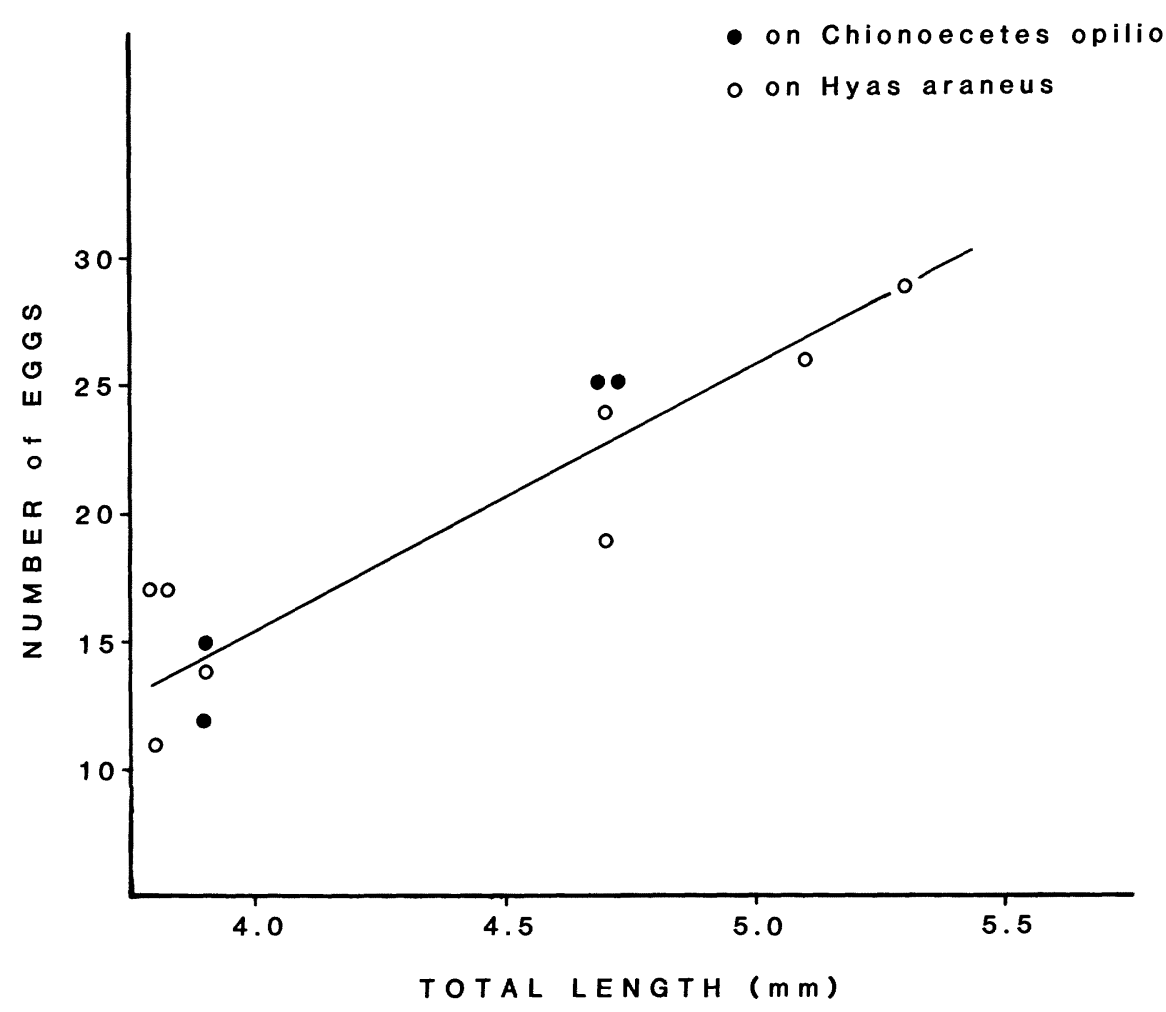

Fig. 3. Fecundity of Gammaropsis inaequistylis.

infrequently in dredge and grab samples (personal observation, collections from northern Hudson Bay and Labrador) but the species probably has a circumpolar distribution (Steele, 1961). Considering the diversity of these collections and that they have usually been made only from depths of $100 \mathrm{~m}$ or more, the finding of I. commensalis as a common commensal of Chionoecetes opilio in shallow water was unexpected. That these amphipods regularly occur on the crabs is demonstrated by the early May collections of both 1983 and 1984. Their absence from the late May collections of 1984 suggests that they left the crabs in shallow water. Gammaropsis inaequistylis, described and recorded as Podoceropsis inaequistylis by Shoemaker (1930) from two specimens collected at a depth of $45 \mathrm{~m}$ in the Gulf of St. Lawrence, has been recorded infrequently since then (Steele, 1961; Brunel, 1970). As shown here, it is common on both Hyas araneus and Chionoecetes opilio. Hyas coarctatus, the third spider crab found in Newfoundland waters (Miller and O'Keefe, 1981), has not yet been carefully examined for the presence of amphipods. Since Hyas araneus is known from Labrador to Novaya Zemlya and Chionoecetes opilio has an amphiboreal distribution, being found in both the North Atlantic and North Pacific Oceans (Squires, 1965; Christiansen, 1969), Gammaropsis inaequistylis has a great geographic range in which it might occur. To date it has been reported only from the Northwest Atlantic Ocean.

The similarities in the structures of the gnathopods of $G$. inaequistylis and $I$. commensalis are probably related to their commensal life style on the crabs, but close observations of living animals will be necessary to determine how these gnathopods function. 


\section{LiTERATURE Cited}

Barnard, J. L. 1973. Revision of Corophiidae and related families (Amphipoda).-Smithsonian Contributions to Zoology 61: 1-86.

Besner, M. 1976. Écologie et échantillonage des populations hyperbenthique d'Amphipodes d'un écosystème circalittoral de l'estuaire maritime du Saint-Laurent.-M.Sc. Thesis, Université de Montréal. Pp. 1-183.

Brunel, P. 1970. Catalogue d'invertébrés benthiques du golfe Saint-Laurent recueillis de 1951 à 1966 par la Station de biologie marine de Grande-Rivière.-Travaux sur les Pêcheries du Québec 32: $1-54$.

Chevreux, E. 1900. Amphipodes provenant des campagnes de l'Hirondelle (1885-1888). - Résultats des Campagnes Scientifiques Accomplies sur son Yacht par Albert Ier Prince Souverain de Monaco 16: 1-195.

Christiansen, M. E. 1969. Decapoda Brachyura.-Marine Invertebrates of Scandinavia 2: 1-143.

Conlan, K. E. 1983. The amphipod superfamily Corophioidea in the northeastern Pacific Region. 3. Family Isaeidae: systematics and distributional ecology. - National Museum of Natural Sciences (Ottawa), Publications in Natural Sciences 4: 1-75.

Hooper, R. G. (In press.) A spring breeding migration of the snow crab (Chionoecetes opilio) into shallow water in Newfoundland. - Crustaceana.

Miller, R. J., and P. G. O'Keefe. 1981. Seasonal and depth distribution, size, and molt cycle of spider crabs, Chionoecetes opilio, Hyas araneus, and Hyas coarctatus in a Newfoundland bay.Canadian Technical Report of Fisheries and Aquatic Sciences 1003: i-iv + 1-18.

Shoemaker, C. R. 1930. The Amphipoda of the Cheticamp Expedition.-Contributions to Canadian Biology and Fisheries, New Series 5: 221-359.

Squires, H. J. 1965. Decapod crustaceans of Newfoundland, Labrador and the central eastern Arctic.Fisheries Research Board of Canada, Manuscript Report Series (Biological) 810: 1-212.

Steele, D. H. 1961. Studies in the marine Amphipoda of eastern northeastern Canada. - Ph.D. Thesis, McGill University, Montreal. Pp. 1-350.

- and V. J. Steele. 1969. The biology of Gammarus (Crustacea, Amphipoda) in the northwestern Atlantic. I. Gammarus duebeni Lillj. - Canadian Journal of Zoology 47: 235-244.

Stephensen, K. 1944. Crustacea Malacostraca VIII: Amphipoda IV. - Danish Ingolf Expedition 3(13): $1-51$.

Vader, W. 1983. Prehensile pereopods in gammaridean Amphipoda.-Sarsia 68: 139-148.

RECEIVED: 29 January 198.5.

ACCEPTED: 21 May 1985.

Address: Department of Biology, Memorial University of Newfoundland, St. John's, Newfoundland A1B 3X9, Canada.

\section{ANNOUNCEMENT}

The following opinion has been published by the International Commission on Zoological Nomenclature in the Bulletin of Zoological Nomenclature 42(3): 233.

Calamoecia australica Sars, 1908, and Calamoecia australis (Searle, 1911) (Crustacea, Copepoda): proposals to remove the confusion rejected.

The Commission gives six months notice of the possible use of its plenary powers in the following case, published in the Bulletin of Zoological Nomenclature 42(3) on 30 September 1985, and would welcome comments and advice from interested zoologists.

Neodorippe Serène and Romimohtarto, 1969 (Crustacea, Decapoda): proposed designation of type species.

Correspondence should be addressed to the Executive Secretary, International Commission on Zoological Nomenclature, \% British Museum (Natural History), Cromwell Road, London, SW7 5BD, England. 